\title{
Current status of acute hepatopancreatic necrosis disease (AHPND) and result of isolating AHPND-causing strains of farmed shrimp in Mekong Delta Region of Vietnam
}

\author{
Dung H. T. Mai ${ }^{1,2}$, Binh T. Huynh ${ }^{1,2}$, Hoa T. M. Nguyen ${ }^{1,2}$, Hoan P. K. Nguyen ${ }^{1,2}$, \\ Toan T. Nguyen ${ }^{3}$, Lien T. H. Tran ${ }^{4}$, Ly H. Tien ${ }^{5}$, Xuyen D. Nguyen ${ }^{6}$, \\ Thuoc L. $\operatorname{Tran}^{1,2}$, \& Hieu V. Tran ${ }^{1,2 *}$ \\ ${ }^{1}$ Faculty of Biology and Biotechnology, University of Science, Ho Chi Minh City, Vietnam \\ ${ }^{2}$ Vietnam National University, Ho Chi Minh City, Vietnam \\ ${ }^{3}$ Long An Sub-Department of Livestock Production, Veterinary and Aquaculture, Long An, Vietnam \\ ${ }^{4}$ Ben Tre Sub-Department of Livestock Production, Veterinary, Ben Tre, Vietnam \\ ${ }^{5}$ Faculty of Agriculture, Bac Lieu University, Bac Lieu, Vietnam \\ ${ }^{6}$ Kien Giang Sub-Department of Livestock production, Veterinary, Kien Giang, Vietnam
}

ARTICLE INFO
Research Paper
Received: March 26, 2021
Revised: April 13, 2021
Accepted: April 22, 2021
Keywords
AHPND
ToxA
ToxB
V. parahaemolyticus
Whiteleg shrimp
*Corresponding author
Tran Van Hieu
Email: tvhieu@hcmus.edu.vn

\begin{abstract}
Early mortality syndrome/acute hepatopancreatic necrosis (EMS/AHPND) was first detected in China in 2009. The disease spread rapidly to neighboring countries and emerged in almost major shrimp-producing regions in the world, including Vietnam. The disease has caused serious damage to the global shrimp industry and so far, there is no effective cure. In order to understand the current status of AHPND, and then to introduce effective prevention and detection measures, we collected data and shrimp samples in some provinces in the Mekong Delta to analyze and isolate the pathogenic strains. The results of our study conducted from 2014 - 2018 in four provinces (Ben Tre, Long An, Bac Lieu, Kien Giang) showed that AHPND damaged from 2.0 to $57.2 \%$ of the total shrimp farming area. In addition, we isolated 10 AHPND-positive strains via culturing and PCR. The results of representative sequencing of three strains LA1, LA5, and LA8 showed that they were $100 \%$ similarity with the previously published strain XN89. These isolated strains are used as a collection for further studies on the origin and mechanism of the disease by whole genome sequencing.
\end{abstract}

Cited as: Mai D. H. T., Huynh, B. T., Nguyen, H. T. M., Nguyen, H. P. K., Nguyen, T. T., Tran, L. T. H, Tien, L. H., Nguyen, X. D., Tran, T. L., \& Tran, H. V. (2021). Current status of acute hepatopancreatic necrosis disease (AHPND) and result of isolating AHPND-causing strains of farmed shrimp in Mekong Delta Region of Vietnam. The Journal of Agriculture and Development 20(2), 36-43. 


\title{
Thực trạng bệnh hoại tử gan tụy cấp tính (AHPND) trên tôm nuôi và kết quả phân lập chủng vi khuẩn gây bệnh ở một số tỉnh Tây Nam Bộ
}

\author{
Mai Hoàng Thùy Dung ${ }^{1,2}$, Huỳnh Tuấn Bình ${ }^{1,2}$, Nguyễn Thị Minh Hòa $^{1,2}$, Nguyễn Phước \\ Khải Hoàn ${ }^{1,2}$, Nguyễn Thanh Toàn ${ }^{3}$, Trần Thị Hương Liên ${ }^{4}$, Tiền Hải L ${ }^{5}{ }^{5}$, \\ Nguyễn Đình Xuyên ${ }^{6}$, Trần Linh Thước ${ }^{i, 2}$ \& Trần Văn Hiếu ${ }^{1,2 *}$ \\ ${ }^{1}$ Khoa Sinh Học - Công Nghệ Sinh Học, Trường Đại Học Khoa Học Tự Nhiên TP.HCM, TP. Hồ Chí Minh \\ ${ }^{2}$ Đại Học Quốc Gia Thành Phố Hồ Chí Minh \\ ${ }^{3}$ Chi Cục Chăn Nuôi, Thú Y Và Thủy Sản Long An, Long An \\ ${ }^{4}$ Chi Cục Chăn Nuôi Và Thú Y Tỉnh Bến Tre, Bến Tre \\ ${ }^{5}$ Khoa Nông Nghiệp, Trường Đại Học Bạc Liêu, Bạc Liêu \\ ${ }^{6}$ Chi Cục Chăn Nuôi Và Thú Y Tỉnh Kiên Giang, Kiên Giang
}

\section{THÔNG TIN BÀI BÁO}

Bài báo khoa học

Ngày nhận: 26/03/2021

Ngày chỉnh sửa: 13/04/2021

Ngày chấp nhận: 22/04/2021

Từ khóa

\section{AHPND}

Tôm thẻ chân trắng

ToxA

ToxB

V. parahaemolyticus

*Tác giả liên hệ

Trần Văn Hiếu

Email: tvhieu@hcmus.edu.vn

\section{TÓM TẮT}

Hội chứng chết sớm/hoại tử gan tụy cấp (EMS/AHPND) là bệnh trên tôm được phát hiện đầu tiên ở Trung Quốc năm 2009. Sau đó, bệnh lây lan nhanh chóng ra các nước lân cận và hiện đã có mặt tại hầu hết các vùng sản xuất tôm chính trên thế giới, trong đó có Việt Nam. Bệnh gây ra thiệt hại nghiêm trọng cho ngành tôm toàn cầu và cho đến nay vẫn chưa có phương pháp chữa bệnh hiệu quả. Để nắm rõ thực trạng bệnh AHPND từ đó đưa ra các biện pháp phát hiện và phòng ngừa hiệu quả thì chúng tôi đã thu thập dữ liệu thực tế ở một số tỉnh thuộc Đồng bằng sông Cửu Long để phân tích cũng như thu thập mẫu tôm để phân lập chủng vi khuẩn Vibrio parahaemolyticus gây bệnh. Nghiên cứu từ năm 2014 - 2018 ở bốn tỉnh Bến Tre, Long An, Bạc Liêu, Kiên Giang cho thấy diện tích thiệt hại của AHPND dao động trong khoảng 2,0 - 57,2\% tổng diện tích nuôi tôm. Ngoài ra, chúng tôi cũng phân lập được 10 chủng dương tính với $\mathrm{AHPND}$ thông qua nuôi cấy và $\mathrm{PCR}$. Kết quả giải trình tự đại diện ba chủng LA1, LA5, và LA8 cho thấy có độ tương đồng $100 \%$ với chủng gây bệnh XN89 đã được công bố trước đây. Các chủng phân lập này sẽ được sử dụng để tạo bộ sưu tập chủng gây bệnh nhằm nghiên cứu sâu hơn cơ chế và nguồn gốc bệnh thông qua giải trình tự toàn bộ bộ gen.

\section{1. Đặt Vấn Đề}

Ngành công nghiệp nuôi tôm có giá trị không nhỏ trong thị trường nuôi trồng thủy sản của thế giới và cả ở Việt Nam. Ước tính trong năm 2019, sản lượng tôm của Việt Nam đạt khoảng 700 nghìn tấn chiếm khoảng $15 \%$ thế giới về tổng sản lượng tôm và đứng hai thế giới kể từ 2016 cho đến nay theo thống kê của The Global Aquaculture Alliance (Anderson \& ctv., 2019). Diện tích tôm nuôi nước lợ cả năm 2018 đạt 712,7 nghìn ha chiếm $64,4 \%$ diện tích nuôi trồng thủy sản của Việt Nam. Khu vực nuôi tôm chủ yếu là Đồng bằng sông Cửu Long (ĐBSCL), chiếm đến 80,61\% sản lượng và chiếm $91 \%$ diện tích nuôi tôm của cả nước.

Với quy mô nuôi tôm công nghiệp mật độ cao và dinh dưỡng nhiều, tôm rất dễ bị bệnh nếu quản lý mầm bệnh không tốt. Đặc biệt, trong số đó bệnh hoại tử gan tụy cấp (AHPND) với tốc độ lây lan nhanh và gây ra thiệt hại kinh tế trầm trọng. Bệnh AHPND lần đầu được ghi nhận ở Trung Quốc vào năm 2009 sau đó lan ra châu Á và các nước ở khu vực khác: Việt Nam (2010), Malaysia (2011), Thái Lan (2012), Mexico (2013) và Philippines (2015) (Flegel \& ctv., 2012; SotoRodriguez \& ctv., 2015). Hoại tử gan tụy cấp đã gây thiệt hại nặng cho ngành nuôi tôm châu Á lên đến 1 tỷ USD vào năm 2013 theo ước tính của 
Liên minh nuôi trồng thủy sản toàn cầu. Bệnh AHPND có thể xuất hiện và gây chết cho tôm trong vòng 45 ngày sau khi thả, tỉ lệ chết có thể lên đến 100\% sau khi nhiễm bệnh (GAA, 2013).

Ở Việt Nam, bệnh xảy ra hầu hết các tháng trong năm, nhưng tập trung nhiều từ tháng 3 đến tháng 8 dương lịch hằng năm. Triệu chứng của tôm bệnh thường bỏ ăn, tấp mé, có gan tụy nhạt màu. Quan sát mô học, các tế bào gan tụy có đầy đủ các đặc tính hoại tử như các tế bào bị bong tróc, tập trung rất nhiều tế bào máu ở xung quanh và khoảng gian giữa ống gan tụy bị tổn thương và xảy ra nhiễm khuẩn thứ cấp nặng ở gian đoạn cuối. Vi khuẩn Vibrio parahaemolyticus ( $V . p$ ) là nguyên nhân gây bệnh hoại tử gan tụy cấp ở tôm. Yang \& ctv. (2014) phát hiện plasmid mới trên loài này, đặt tên là pVA1 kích thước khoảng $69 \mathrm{~kb}$ gồm hai gen độc tố của bệnh gen pir $\mathrm{A}^{\mathrm{vp}}(336 \mathrm{bp})$ và pir $\mathrm{B}^{\mathrm{vp}}(1317 \mathrm{bp})$ nằm trong vùng có kích thước $3,5 \mathrm{~kb}$ được bao bởi các vùng lặp đảo của trình tự mã hóa chuyển vị. Plasmid pVA1 đã được chứng minh là nguồn duy nhất sinh ra độc tố ToxAB gây chết các tế bào gan tụy đặc điểm của bệnh AHPND (Lee \& ctv., 2015).

Sau hiểu biết về gen độc tố và plasmid pVA1, hàng loạt các công bố sau đó báo cáo rằng còn có các loài khác $V$. p thuộc họ Vibrio khác gây ra bệnh AHPND như một loài giống với $V$. harveyi, $V$. campbellii, $V$. owensii và $V$. punensis (Kondo \& ctv., 2015; Liu \& ctv., 2015; Restrepo \& ctv., 2018), cũng như cung cấp bằng chứng về chuyển gen ngang giữa chủng $V$. campbellii gây bệnh AHPND sang chủng V. owensii không gây bệnh AHPND và trở thành chủng gây chết tôm (Dong \& ctv., 2019).

Hiện nay, có nhiều phản ứng thiết kế để phát hiện bệnh AHPND như PCR, PCR định lượng dùng mẫu dò TaqMan (Han \& ctv., 2015) và kỹ thuật khuếch đại đẳng nhiệt qua trung gian cấu trúc kẹp tóc (LAMP) (Kongrueng \& ctv., 2015) được thiết kế để phát hiện bệnh AHPND. Trong đó, phương pháp AP3 khuếch đại gen toxA (Sirikharin \& ctv., 2014) và phương pháp multiplex-PCR phát hiện cùng lúc toxA, toxB bằng cặp mồi VpPirA-284 và $\mathrm{VpPirB-392} \mathrm{được}$ sử dụng phổ biến nhất trong chuẩn đoán bệnh EMS/AHPND (Devadas \& ctv., 2019).

Với tốc độ lây lan và thiệt hại kinh tế gây ra bởi AHPND, tuy nhiên dữ liệu về tình hình dịch bệnh này trên vùng ĐBSCL chỉ mới cập nhật đến năm 2017 và chỉ ở mức có hay không có dịch ở các tỉnh. Đánh giá thực trạng bệnh trên tôm các tỉnh với mục tiêu cung cấp thông tin và cái nhìn chính xác về mức độ nguy hiểm của $\mathrm{AHPND}$ để có các biện pháp đề phòng, xét nghiệm và chữa trị phù hợp là những gì bài báo sẽ thực hiện. Chúng tôi thực hiện thống kê mô tả trên bộ dữ liệu về tình hình bệnh AHPND trên tôm của bốn tỉnh Long An, Bến Tre, Bạc Liêu, và Kiên Giang cho thấy mức độ nhiễm và lượng thiệt hại bởi bệnh trên quy mô nuôi tôm từng tỉnh. Cùng với đó, đánh giá mức độ nhiễm bệnh trong 150 mẫu tôm đã thu thập được từ Long An, Bến Tre, Bạc Liêu, Kiên Giang bằng phương pháp phân lập chủng vi sinh và xác nhận đồng thời sự hiện diện của vector pVA1 và gen mã hóa toxA gây bệnh AHPND bằng kỹ thuật PCR.

\section{Vật Liệu và Phương Pháp Nghiên Cứu}

2.1. Thu thập mẫu tôm thẻ chân trắng và thông tin chung về tình hình sản lượng tôm và thiệt hại do AHPND trên các tỉnh

Thông tin tình hình sản lượng tôm và thiệt hại do AHPND trên các tỉnh và hộ nuôi được thu thập và tổng hợp bởi các chuyên viên của Chi cực Chăn nuôi và Thú y của bốn tỉnh Long An, Bến Tre, Bạc Liêu, và Kiên Giang dưới dạng báo cáo hiện trạng nuôi trồng thủy sản, trong đó có phiếu điều tra soạn sã̃n gồm ba phần: i) Ngày thả nuôi và thông tin phát hiện dấu hiệu bệnh, ii) Đặc điểm ao nuôi, iii) Xét nghiệm AHPND trên tôm giống và việc dùng kháng sinh khi nuôi và iv) Ước tính doanh thu và thiệt hại. Các phiếu điều tra này sẽ được dùng khảo sát hộ nuôi tôm khi thu mẫu tôm thẻ chân trắng (Litopenaeus vannamei).

\subsection{Phương pháp thống kê mô tả}

Phương pháp thống kê mô tả với các giá trị tổng, kết hợp với phần trăm để mô tả thông tin chung của hộ nuôi, thực trạng của mô hình nuôi tôm. Vai trò của tôm nuôi cũng như tác động của dịch bệnh trên tôm nuôi đối với kinh tế hộ cũng được trình bày theo cách này.

\subsection{Phương pháp phân lập, nuôi cấy và định danh chủng vi khuẩn gây AHPND bằng PCR}

Các mẫu từ cá thể tôm tôm thẻ chân trắng (Litopenaeus vannamei) ở Long An, Bến Tre, Bạc Liêu và Kiên Giang được thu thập từ 150 ao thuộc các hộ nuôi thâm canh tôm xuất hiệu các dấu hiệu 


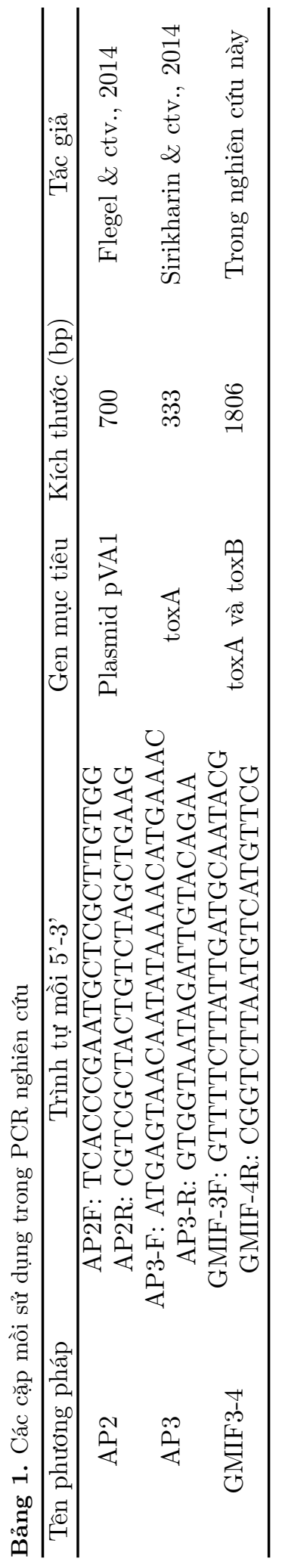

lâm sàng của bệnh AHPND được nghiền nát đầu và tăng sinh qua đêm trong môi trường Tryptic Soy Broth (TSB) có bổ sung 1,5\% NaCl. Dịch tăng sinh sau đó được pha loãng liên tiếp bậc 10 tới $10^{-3}$ rồi trải $50 \mu \mathrm{L}$ dịch pha loãng lên môi trường Hicrome ${ }^{T M}$ Vibrio agar và để tăng sinh ở $37^{\circ} \mathrm{C}$ qua đêm. Chọn 5-10 khuẩn lạc dự tuyển có màu xanh ngọc lam đem thực hiện multiplex $\mathrm{PCR}$ với cặp mồi $\mathrm{AP} 2$ và mồi $\mathrm{AP} 3$ để xác định tương ứng chủng có vector (pVA1) và gen (toxA) gây bệnh. Khuẩn lạc cho kết quả dương tính sẽ được hoạt hóa trong TSB có bổ sung 1,5\% NaCl qua đêm để tiến hành bảo quản với glycerol nhằm chuẩn bị cho giải trình tự mã hóa độc tố toxA, toxB gây AHPND trên tôm.

\subsection{Giải trình tự hai gen mã hóa độc tố toxA và toxB}

Khuẩn lạc cho kết quả dương tính cặp mồi AP3 từ ông trữ chủng chứa glycerol $20 \%$ sẽ được hoạt hóa bằng cách thêm vào ống nghiệm chứa $5 \mathrm{~mL}$ $\mathrm{TSB}$ có bổ sung $1,5 \% \mathrm{NaCl}$ lắc ở $37^{\circ} \mathrm{C}$ qua đêm và thực hiện $\mathrm{PCR}$ thu gen giải trình tự. Để thu được trình tự mã hóa đồng thời độc tố tox $\mathrm{A}$ và toxB, chúng tôi thiết kế cặp mồi GMIF3-4 (Bảng 1) nằm bên ngoài vùng gen mã hóa tương ứng cho toxA và toxB về phía thượng nguồn và hạ nguồn. Sản phẩm PCR từ cặp mồi này (1806bp) được gửi giải trình tự tại công ty KTest, Việt Nam bằng kỹ thuật Sanger. Kết quả trình tự được xử lý bằng phần mềm BioEdit phiên bản 7.2 và sắp giống cột bằng Clustal Omega (EMBL-EBI, UK). Các trình tự sau khi sắp gióng cột được chú giải và công bố trên Ngân hàng gen.

\section{Kết Quả và Thảo Luận}

\subsection{Thông tin chung về tình hình sản lượng tôm và thiệt hại do AHPND trên các tỉnh và hộ nuôi}

Từ năm 2014 đến năm 2018, bốn tỉnh thuộc ĐBSCL gồm Long An, Bến Tre, Bạc Liêu và Kiên Giang có tổng diện tích nuôi tôm trung bình trong bốn năm lần lượt là: $6.600,35.000$, $135.319,123.859$ ha và về mặt tổng sản lượng tôm là: 11.500, 55.900, 126.358, 73.390 tấn (Bảng 2). Tỉ lệ diện tích tôm nuôi luôn chiếm một tỉ lệ cao trên tổng diện tích nuôi trồng thủy sản của bốn tỉnh (thấp nhất là Kiên Giang với 50,38\% và cao nhất là Bạc Liêu với 96,94\%) (Bảng 3). Cùng với tỉ lệ này, bốn tỉnh này tỉnh đang xu hướng chuyển 
Bảng 2. Kết quả nuôi tôm ở bốn tỉnh Bến Tre, Long An, Bạc Liêu, Kiên Giang trung bình của năm 2014 - 2018*

\begin{tabular}{lcccc}
\hline Tỉnh & Bến Tre & Long An & Bạc Liêu & Kiên Giang \\
\hline Diện tích nuôi trồng thủy sản (ha) & 46,7 & 10,0 & 134,7 & 215,9 \\
Sản lượng nuôi trồng thủy sản (tấn) & 256,6 & 42,1 & 203,5 & 199,1 \\
Diện tích nuôi tôm (ha) & 35,2 & 6,4 & 130,8 & 108,3 \\
Sản lượng tôm (tấn) & 52,5 & 1,8 & 54,5 & 59,8 \\
Diện tích thiệt hại do AHPND (ha) & 354,0 & 21,0 & 16,2 & 26,4 \\
\hline
\end{tabular}

*Nguồn: Nguyen (2019); Nguyen (2019); Tien (2019); Tran (2019).

Bảng 3. Kết quả nuôi tôm có ảnh hưởng của AHPND trung bình ở bốn tỉnh Long An, Bến Tre, Bạc Liêu, và Kiên Giang qua các năm*

\begin{tabular}{lccccc}
\hline Thời gian & 2014 & 2015 & 2016 & 2017 & 2018 \\
\hline Diện tích nuôi trồng thủy sản (ha) & 89,1 & 97,6 & 103,2 & 142,0 & 110,4 \\
Sản lượng nuôi trồng thủy sản (tấn) & 159,4 & 166,6 & 171,4 & 236,2 & 191,5 \\
Diện tích nuôi tôm (ha) & 64,5 & 67,5 & 69,8 & 96,4 & 75,2 \\
Sản lượng tôm (tấn) & 54,9 & 54,0 & 56,9 & 64,0 & 66,8 \\
Diện tích thiệt hại do AHPND (ha) & 4,2 & 6,1 & 39,9 & 2,0 & 1,5 \\
Tỉ lệ diện tích thiệt hại (\%) & 6,5 & 9,0 & 57,2 & 2,1 & 2,0 \\
\hline *Nồn: Non
\end{tabular}

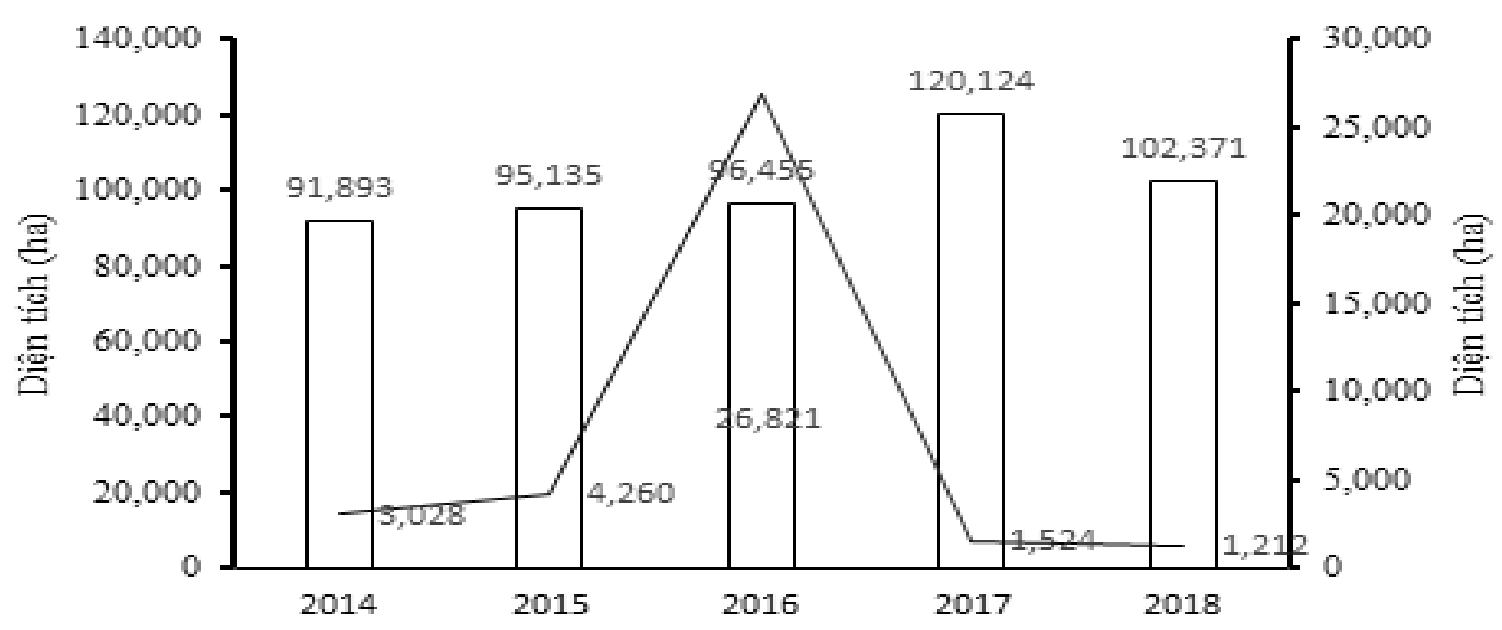

凹Tổng điện tich nuôi tôm (ha) — Diện tich thiệt hại do AHPND (ha)

Hình 1. Biểu đồ ảnh hưởng của AHPND qua các năm của bốn tỉnh.

dịch từ nuôi tôm sú (Penaeus monodon) dần sang nuôi tôm thẻ chân trắng (Litopenaeus vannamei) giống như xu hướng thế giới. Xu hướng này được thúc đẩy vào khoảng năm 2000, tôm thẻ chân trắng với ưu thế ngưỡng chịu mặn rộng và các thông số môi trường tốt được giới thiệu là loài thay thế tôm sú sau đợt tàn phá nặng nề bởi dịch bệnh virus trước đó. Nhưng thực sự tôm thẻ chân trắng có ít bệnh hơn tôm sú hay không thì vẫn chưa được làm rõ, bởi mầm bệnh nguy hiểm của loại tôm này luôn tồn tại tiềm ẩn trong môi trường như các loài thuộc chi Vibrio (Sanathkumar \& ctv., 2014).

\subsection{Tình hình dịch bệnh AHPND trên tôm nuôi 4 tỉnh Long An, Bến Tre, Bạc Liêu, và Kiên Giang từ năm 2014 đến năm 2018}

Bốn tỉnh Long An, Bến Tre, Bạc Liêu, và Kiên Giang có diện tích thiệt hại của AHPND dao động trong khoảng 2,0 - 57,2\% tổng diện tích nuôi tôm trong giai đoạn 2014 - 2018. Tỉ lệ thiệt hại 
Bảng 4. Kết quả điều tra hộ nuôi trung bình ở các tỉnh khảo sát

\begin{tabular}{lcccc}
\hline \multirow{2}{*}{ Nội dung điều tra } & \multicolumn{4}{c}{ Kết quả } \\
\cline { 2 - 5 } & Long An & Bến Tre & Bạc Liêu & Kiên Giang \\
\hline $\begin{array}{l}\text { Số ngày nuôi đến khi phát hiện dấu } \\
\text { hiệu bệnh (ngày) }\end{array}$ & 49 & 42 & 32 & 47 \\
Xét nghiệm AHPND trên tôm giống & \multicolumn{4}{c}{$100 \%$} \\
Tồn thất ao nuôi (đồng) & $24.564 .710,0$ & $40.833 .333,0$ & $26.620 .690,0$ & $36.037 .037,0$ \\
\hline
\end{tabular}

tập trung vào hai tỉnh Bạc Liêu và Kiên Giang, cũng là hai tỉnh có diện tích nuôi tôm lớn.

Từ Hình 1 cho thấy mức độ thiệt hại do bệnh AHPND từ năm 2014 - 2018 lập đỉnh vào năm 2016 và có xu hướng giảm dần sau đó. Qua đó cho thấy rằng việc phòng ngừa và ngăn chặn dịch bệnh AHPND đã và đang rất được người dân và các cấp chính quyền địa phương quan tâm. Người nông dân đã tiếp cận được với các phương pháp phòng ngừa dịch bệnh và có đầu tư ao nuôi, các phương pháp phát hiện bệnh cũng được triển khai. Vì thế, diện tích thiệt hại do AHPND có xu hướng giảm trong năm 2017 - 2018.

\subsection{Thông tin chung về tình hình nuôi tôm và thiệt hại do AHPND trên các hộ nuôi}

Hầu hết các hộ nuôi tôm được khảo sát ở Long An, Bến Tre, Bạc Liêu, Kiên Giang có mức độ đầu tư ao nuôi chưa thể cách ly hoàn toàn mầm bệnh là đa số mới chỉ có lưới xung quanh, có dụng cư riêng cho từng ao, có lót bạt bờ và một số ít lót hoàn toàn hoặc đầu tư kỹ càng hơn. Tất cả hộ nuôi không thực hiện xét nghiệm lại do tốn chi phí và thời gian, dù đã xét AHPND trên tôm giống trước khi thả nuôi. Số ngày nuôi đến khi phát hiện bệnh của các tỉnh từ 32 - 49 ngày là phát hiện dấu hiệu bệnh trong vòng 45 ngày sau khi thả nuôi và tổn thất trên một ao nuôi trong khoảng 24 đến 36 triệu (GAA, 2013). Trong đó, Bạc Liêu có số ngày nuôi đến khi phát hiện dấu hiệu bệnh ngắn nhất là 32 ngày, ngược lại, Long An có số ngày dài nhất là 49 ngày nhưng do có quy mô nuôi tôm trung bình nhỏ nhất nên có thể là lý do cho việc có tổn thất ao nuôi ít nhất (Bảng $4)$.

3.4. Phân lập chủng AHPND trên tôm nuôi (Litopenaeus vannamei) của bốn tỉnh Tây Nam Bộ

Tổng số 10 chủng $V$. parahaemolyticus dương tính với AHPND trong 150 mẫu tôm (Litopenaeus vannamei) đã được phân lập. Tỉ lệ mẫu tôm dương tính với AHPND trong các mẫu thu thập được là 6,7\% (Bảng 5). Đại diện ba chủng

Bảng 5. Tần suất xuất hiện của $V$. parahaemolyticus gây bệnh hoại tử gan tụy cấp (AHPND) của bốn tỉnh trong năm 2018 - 2020

\begin{tabular}{lcc}
\hline Tỉnh & $\begin{array}{c}\text { Mẫu có khuẩn } \\
\text { lạc dương } \\
\text { tính AHPND }\end{array}$ & $\begin{array}{c}\text { Mẫu nghi ngờ } \\
\text { bệnh }\end{array}$ \\
\hline Long An & 6 & 50 \\
Bến Tre & 4 & 40 \\
Bạc Liêu & 0 & 30 \\
Kiên Giang & 0 & 30 \\
Tồng mẫu & 10 & 150 \\
\hline Tần suất & $6,7 \%$ & \\
xuất hiện & \\
\hline
\end{tabular}

Bảng 6. Thông tin gen mã hóa độc tố toxA và toxB từ một số chủng $V$. parahaemolyticus gây bệnh hoại tử gan tụy cấp (AHPND) đại diện phân lập được

\begin{tabular}{ccc}
\hline Tên chủng & Gen & $\begin{array}{c}\text { Mã số đăng ký trên } \\
\text { ngân hàng gen }\end{array}$ \\
\hline \multirow{2}{*}{ LA1 } & ToxA & MW355905 \\
& ToxB & MW355906 \\
\multirow{2}{*}{ LA5 } & ToxA & MW355907 \\
& ToxB & MW355908 \\
LA8 & ToxA & MW355909 \\
& ToxB & MW355910 \\
\hline
\end{tabular}

dương tính đặc trưng về gen của AHPND (dương tính với plasmid và gen toxA) được gửi giải trình tự cả gen toxA và toxB (Hình 2). Các kết quả về trình tự này được công bố trên ngân hàng gen với các thông tin và mã số tương ứng (Bảng 6). Kết quả giải trình tự đại diện cho ba chủng LA1, LA5, LA8 được thể hiện trong Hình 3 cho thấy các chủng này có độ tương đồng cao với chủng XN89 là chủng gây bệnh AHPND đã được công bố trên Ngân hàng gen. Để tìm hiểu rõ hơn về nguồn gốc bệnh và cơ chế lây lan của bệnh $\mathrm{AH}$ PND thông qua chuyển gen, giải trình tự toàn bộ plasmid chứa gen toxA/toxB từ những chủng 


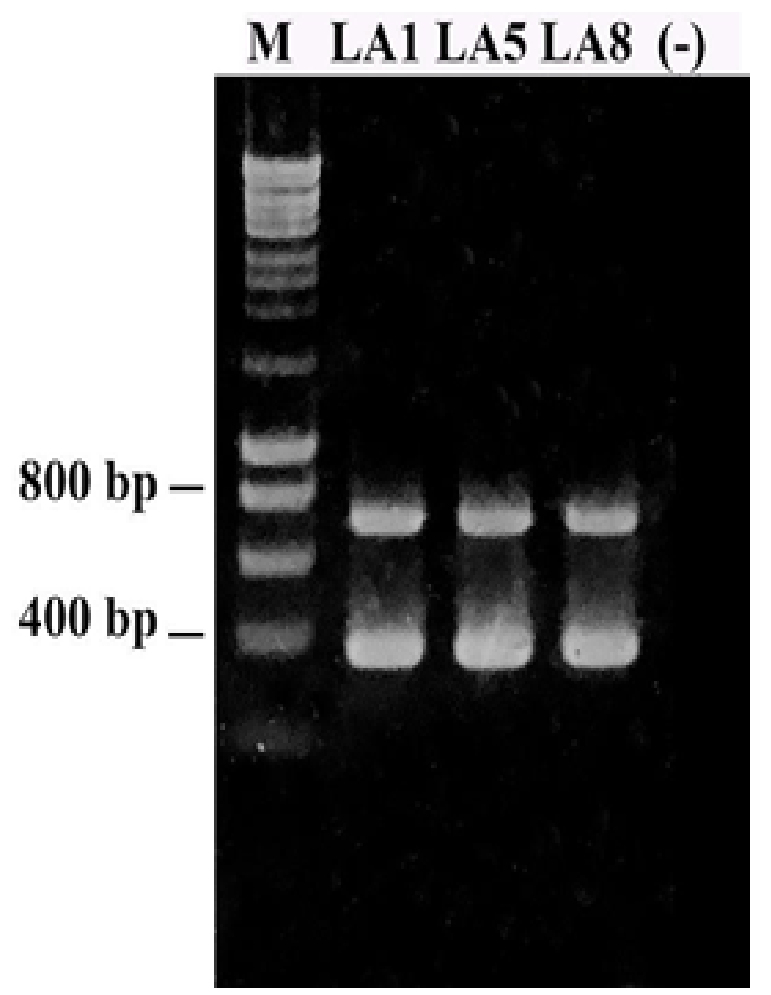

Hình 2. Kết quả PCR kiểm tra đại diện ba chủng dương tính với bệnh hoại tử gan tụy cấp (AHPND) đã phân lập với các cặp mồi $\mathrm{AP} 3$ và AP2. Các ký hiệu $\mathrm{M}$, Thang $1 \mathrm{~kb}$; giếng 1 đến 3 , kết quả đại diện cho các chủng dương tính AHPND; (-), chứng âm.

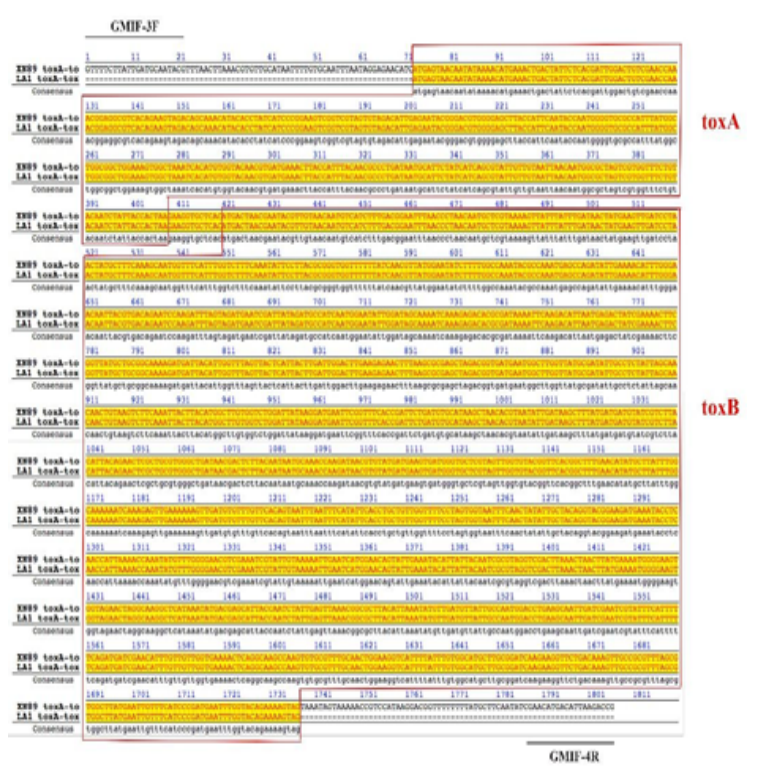

Hình 3. Kết quả giải trình tự đại diện của chủng LA1. dương tính đã phân lập là một điều cần thiết.

\section{Kết Luận}

Các tỉnh thuộc ĐBSCL là những khu vực nuôi tôm chủ yếu của cả nước tuy nhiên vẫn còn bị thiệt hại do AHPND qua mỗi năm. Diện tích nuôi tôm luôn chiếm ở mức cao trong diện tích nuôi trông thủy sản ở bốn tỉnh.

Dịch bệnh APHND luôn xuất hiện qua các năm với đỉnh điểm gây thiệt hại nặng vào năm 2016. Sau đó diện tích bị bệnh suy giảm về mức gần như lúc đầu và diện tích nuôi tôm có tăng dù cho đợt ảnh hưởng nặng 2016.

Nhờ vào ý thức của các hộ dân khi bệnh càng ngày càng phổ biến hơn thì mức độ thiệt hại có giảm nhẹ từ năm 2017 - 2018. Dù có thực hiện xét hiện con giống nhưng các thành phần khác của ao nuôi và các giai đoạn sau chưa được quan tâm xét nghiệm bệnh AHPND, cũng như là mức độ đầu tư ao nuôi chưa đủ cách ly với mầm bệnh hiệu quả.

Chúng tôi cũng đã phân lập được 10 chủng dương tính với độc tố toxA thông qua nuôi cấy và $\mathrm{PCR}$ cũng như lần đầu tiên công bố trình tự các gen mã hóa cho hai độc tố toxA và toxB từ các một số chủng đại diện trên Ngân hàng gen. Dự kiến, chúng tôi sẽ phân lập thêm chủng dương tính mới tiến hành giải trình tự toàn bộ plasmid chứa gen toxA/toxB để tìm hiểu rõ hơn về nguồn gốc bệnh và cơ chế lây lan của bệnh AHPND thông qua chuyển gen.

\section{Lời Cảm Ơn}

Đề tài nghiên cứu được tài trợ từ Chương trình khoa học và công nghệ cấp quốc gia phục vụ phát triển bền vững vùng Tây Nam Bộ, mã số KHCNTNB.ĐT/14-19/C31.

\section{Tài Liệu Tham Khảo (References)}

Anderson, J. L., Valderrama, D., \& Jory, D. E. (2019). GOAL 2019: Global shrimp production review. Retrieved November 4, 2019, from https://www.aquaculturealliance.org/advocate/goal2019-global-shrimp-production-review.

Devadas, S., Banerjee, S., Yusoff, F. M., Bhassu, S., \& Shariff, M. (2019). Experimental methodologies and diagnostic procedures for acute hepatopancreatic necrosis disease (AHPND). Aquaculture 499, 389-400.

Dong, X., Chen, J., Song, J., Wang, H., Wang, W., Ren, Y., \& Huang, J. (2019). Evidence of the horizontal transfer of pVA1-type plasmid from AHPND-causing 
V. campbellii to non-AHPND V. owensii. Aquaculture 503, 396-402.

Flegel, T. W. (2012). Historic emergence, impact and current status of shrimp pathogens in Asia. Journal of Invertebrate Pathology 110(2), 166-173.

GAA (Global Aquaculture Alliance). (2013). Cause of EMS shrimp disease identified. GAA's GOAL 2013 conference. Paris, France: Global Aquaculture Alliance. Retrieved February 25, 2015, from https://www.aquaculturealliance.org/blog/cause-ofems-shrimp-disease-identified.

Han, J. E., Tang, K. F., Pantoja, C. R., White, B. L., \& Lightner, D. V. (2015). qPCR assay for detecting and quantifying a virulence plasmid in acute hepatopancreatic necrosis disease (AHPND) due to pathogenic Vibrio parahaemolyticus. Aquaculture 442, 12-15.

Kondo, H., Van, P. T., Dang, L. T., \& Hirono, I. (2015). Draft genome sequence of non-Vibrio parahaemolyticus acute hepatopancreatic necrosis disease strain KC13. 17.5, isolated from diseased shrimp in Vietnam. Genome Announcements 3(5): e00978-15.

Kongrueng, J., Tansila, N., Mitraparp-arthorn, P., Nishibuchi, M., Vora, G. J., \& Vuddhakul, V. (2015). LAMP assay to detect Vibrio parahaemolyticus causing acute hepatopancreatic necrosis disease in shrimp. Aquaculture International 23(5), 1179-1188.

Lee, C. T., Chen, I. T., Yang, Y. T., Ko, T. P., Huang, Y. T., Huang, J. Y., \& Lo, C. F. (2015). The opportunistic marine pathogen Vibrio parahaemolyticus becomes virulent by acquiring a plasmid that expresses a deadly toxin. Proceedings of the National Academy of Sciences 112(34), 10798-10803.

Liu, L., Xiao, J., Xia, X., Pan, Y., Yan, S., \& Wang, Y. (2015). Draft genome sequence of Vibrio owensii strain SH-14, which causes shrimp acute hepatopancreatic necrosis disease. Genome Announcements 3(6), e01395-15.

Nguyen, D. X. (2019). Acute hepatopancreatic necrosis disease on shrimp cultured in Kien Giang province (research report). Kien Giang Sub-Department of Livestock Production, Veterinary and Aquaculture, Kien Giang, Vietnam.

Nguyen, T. T. (2019). Acute hepatopancreatic necrosis disease on shrimp cultured in Long An province (research report). Long An Sub-Department of Livestock production, Veterinary and Aquaculture, Long An, Vietnam.
Restrepo, L., Bayot, B., Arciniegas, S., Bajaña, L., Betancourt, I., Panchana, F., \& Muñoz, A. R. (2018). PirVP genes causing AHPND identified in a new Vibrio species (Vibrio punensis) within the commensal Orientalis clade. Scientific Reports 8(1), 1-14.

Sanathkumar, H., Ravi, C., Padinhatupurayil, S. B., Mol, M., Prasad, J. K., \& Nayak, B. B. (2014). Microbiological investigation of persistent mortalities in Litopenaeus vannamei grown in low saline waters in India. Journal of Aquatic Animal Health 26(3), 154-159.

Sirikharin, R., Taengchaiyaphum, S., Sritunyalucksana, K., Thitamadee, S., Flegel, T. W., Mavichak, R., \& Proespraiwong, P. (2014). A new and improved PCR method for detection of AHPND bacteria. Retrieved June 18, 2014, from https://enaca.org/?id=96.

Soto-Rodriguez, S. A., Gomez-Gil, B., Lozano-Olvera, R., Betancourt-Lozano, M., \& Morales-Covarrubias, M. S. (2015). Field and experimental evidence of Vibrio parahaemolyticus as the causative agent of acute hepatopancreatic necrosis disease of cultured shrimp (Litopenaeus vannamei) in Northwestern Mexico. Applied and Environmental Microbiology 81(5), 16891699.

Tien, H. L. (2019). Acute hepatopancreatic necrosis disease on shrimp cultured in Bac Lieu province (research report). Bac Lieu University, Bac Lieu, Vietnam.

Tran, T. H. L. (2019). Acute hepatopancreatic necrosis disease on shrimp cultured in Ben Tre province (research report). Ben Tre Sub-Department of Livestock Production, Veterinary and Aquaculture, Ben Tre, Vietnam.

Yang, Y. T., Chen, I. T., Lee, C. T., Chen, C. Y., Lin, S. S., Hor, L. I., \& Lo, C. F. (2014). Draft genome sequences of four strains of Vibrio parahaemolyticus, three of which cause early mortality syndrome/acute hepatopancreatic necrosis disease in shrimp in China and Thailand. Genome Announcements 2(5), e0081614. 